DOI https://doi.org/10.30525/978-9934-26-004-9-67

\title{
ОСНОВНІ ЗАСАДИ РЕСТАВРАЦІЇ ДВОСТОРОННІХ ХОРУГВ НА ПРИКЛАДІ РЕСТАВРАЦЇ̈ ХОРУГВИ КІНЦЯ 18 СТОЛІТТЯ «БОГОРОДИЦЯ 3 ДИТЯМ/ТРИ СВЯТИТЕЛІ» З КОЛЕКЦЇ̈ НАЦІОНАЛЬНОГО МУЗЕЮ У ЛЬВОВІ ІМЕНІ МИТРОПОЛИТА АНДРЕЯ ШЕПТИЦЬКОГО
}

\author{
Шарова Н. М. \\ викладач консерваційно-реставраційного практикуму \\ кафедри реставраиії творів мистеитв \\ Львівської національної академії мистецтв, \\ завідуюча відділом реставраиії олійного малярства \\ Національного музею у Львові \\ імені митрополита Андрея Шептицького \\ м. Львів, Украӥна
}

Національний музей у Львові закладений 1905 року грекокатолицьким митрополитом Андреєм Шептицьким як приватна фундація. У 1913 році урочистим актом переданий в дар українському народові, відтоді на його теренах започатковано і реставраційну справу, яка розвивається й до сьогодення.

Музей володіє найбільшою збіркою українського мистецтва (від 12 століття до сьогодення), та налічує понад 170000 одиниць збереження різноманітних артефактів та репрезентує вікові традиції розвитку української національної культури. В експозиції представлено найбільше та найповніше зібрання українського середньовічного сакрального мистецтва XII-XVIII ст.: іконопис, рукописи та стародруки, декоративна різьба, металопластика, гаптовані тканини, а також пам'ятки українського бароко - Жовківський та Богородчанський іконостаси та український живопис кінця XVIII - XIX ст.

Предметом особливої гордості $є$ найбільша й найповніша в Україні колекція середньовічного українського сакрального мистецтва XII-XVIII століть. Це ікони, скульптура, рукописи і стародруки, декоративна різьба, металопластика та гаптовані церковні тканини. Найбільш багатогранно у збірці музею представлена ікона XIV-XVIII ст., здебільшого з теренів Західної України [1].

У 2009 році Національний музей у Львові презентував громаді Львова та всієї України виставку «Українські хоругви» куратором якої 254 
виступила доцент ЛНАМ, кандидат мистецтвознавства, наукова співробітниця музею - Роксолана Косів.

Українські хоругви - важлива складова вітчизняної художньої культури. У них віддзеркалені смаки та вподобання кожної епохи, політичні події та релігійні настанови часу, це символи незалежності та віри, з якими наші предки ходили у військові походи, відстоювали вірність Церкві. В ансамблі храмового комплексу церковні хоругви були важливим елементом облаштування, їх творили в тісному контакті 3 іконописом, гаптуванням, вишивкою, тому хоругви мають чітко виражений національний стиль. Більшість збережених пам'яток цього періоду належить до народної течії іконопису, їхньою характерною рисою є лаконізм, певна обмеженість засобів художнього вислову, що компенсується підкресленим ритмом ліній, кольорових площин, орнаменту [2, ст. 12].

Саме для проведення виставки презентовані твори пройшли повний комплекс реставраційних робіт у відділі реставрації предметів станкового олійного живопису Національного музею у Львові.

У своїй статті намагатимусь розкрити основні складності проведення реставрації двосторонніх творів беручи для прикладу весь процес реставрації конкретної пам'ятки - а саме хоругви 18 століття «Богородиця 3 дитям/Три святителі», переданої до реставраційних майстерень Національного музею у Львові 3 церкви Архистратига Михаїла, села Ісая, Турківського району, Львівської області

Перед початком реставраційних робіт проводимо усі доступні нам техніко-технологічні дослідження (склад грунту, фарбового шару, фото фіксацію в видимих та невидимих (УФ, ІЧ ) променях. Аварійний стан збереження твору потребував негайного реставраційного втручання. Значні стійкі заломи основи, втрати і деформації полотна та товстий шар (подекуди до 7 мм) поверхневих забруднень утруднювали проведення дезінфекції та процесу укріплення зв’язку фарбового шару з грунтом та основою (рис. 1, рис. 2).

Саме тому прийнято рішення обережно але максимально прибрати нашарування пилу та бруду 3 поверхні малярства, використовуючи широкий м'який колонковий пензель, та працюючи під бінокулярною лупою невеликими ділянками. Наступним етапом проведено дезінфекцію методом розпилення антисептика, що в свою чергу злегка зволожило всю поверхню живопису. Процес укріплення розпочали коли антисептування злегка підсохло, але не чекаючи повного його висихання починаючи від центу кожної частини, хрестоподібним способом. щоб уникнути деформацій основи. Після укріплення на обидві частини ставили прес, 
для стабілізації процесу. Далі скріпили дві частини між собою методом «в стик» починаючи від центу і рухаючись до країв хоругви, разом з тим слідкували за спів падінням усіх живописних елементів. Закінчуємо процес розтягуючи твір на робочому підрамнику полосами «крафт» паперу, що дає змогу в подальшому безпечно працювати з нерухомою основою. Далі готуємо полотно для доповнення втрат основи. Зважаючи на те, що в якості основи твору використано льняне полотно, підбираємо максимально наближене льняне полотно по товщині та плетенню до авторського. Перемо його прохолодній воді, висушуємо, розпрасовуємо та натягуємо на підрамник, далі проклеюємо до утворення рівномірної плівки глютенового клею на поверхні полотна. Після висихання клею викроюємо необхідні вставки, слідкуючи за співпадінням напрямку ниток основи та піткання на авторському полотні та реставраційних доповненнях. Методом «в стик» скріплюємо краї авторського та реставраційних полотен, використовуючи перевірений часом спиртовий розчин ПВБ. Місце склеювання, після повного висихання пропрасовуємо каутером та ставимо прес. Основні процеси роботи з основою виконано (рис. 3, рис. 4, рис. 6). Знімаємо профілактику з поверхні малярства. Далі підводимо реставраційний грунт у місцях реставраційних доповнень та втрат авторського. Грунт повинен бути достатньо еластичним і міцним, щоб уникнути небажаних розтріскувань та осипів при роботі з обома сторонами. Після повного висихання шліфуємо реставраційний грунт в рівень авторського малярства.

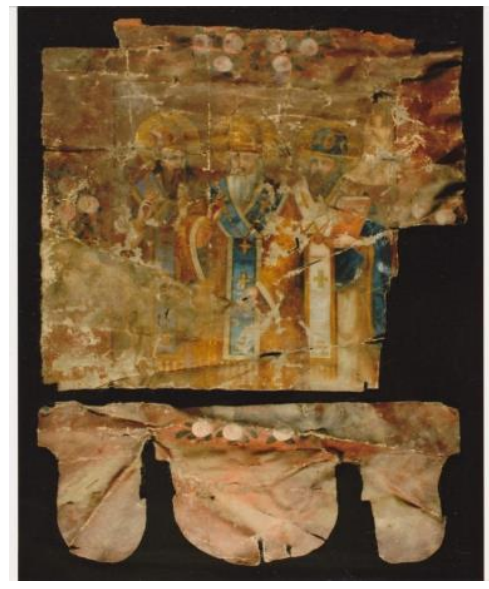

Рис. 1. Сторона В -

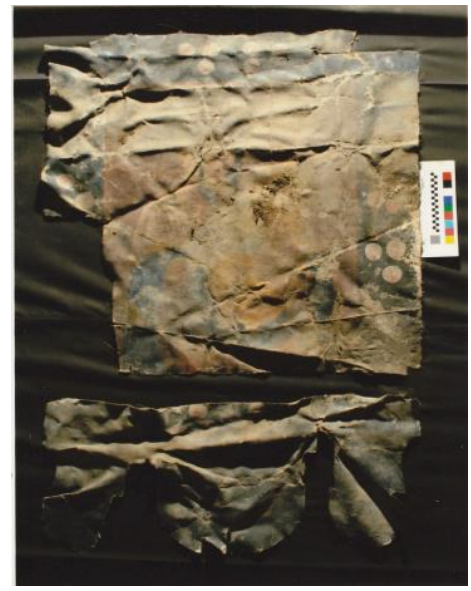

Рис. 2. Сторона А - «Богородиця 


\section{«Три святителі» - до реставрації в прямому освітленні}

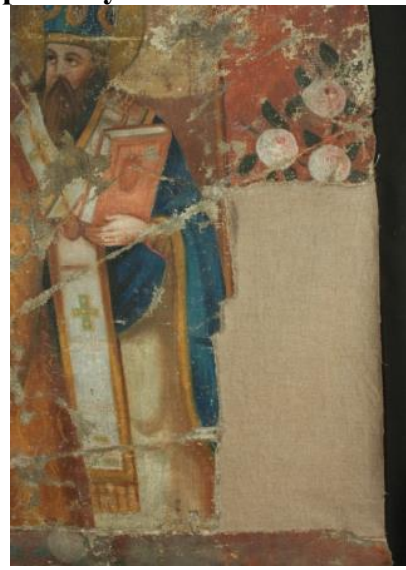

3 дитям» - до реставрації в боковому освітленні

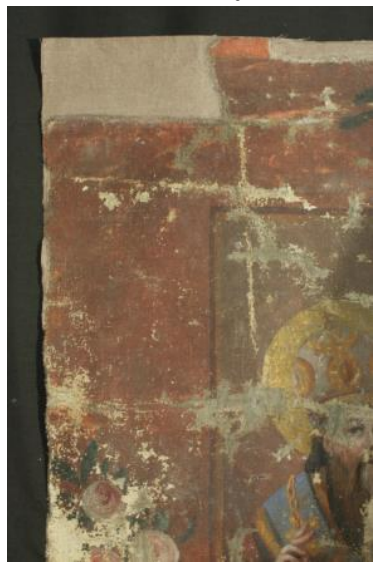

Рис. 3. Рис.4. Фрагмент доповнення авторської основи

Наступним етапом $є$ підбір розчинів для усунення поверхневих забруднень. Починаємо 3 найменш агресивного - дитячого мила $-\mathrm{Ph}$ якого 7, отримуємо задовільний результат. Невеликим ватним тампоном 3 мильним розчином поступово усуваємо поверхневі забруднення з усієї поверхні малярства. Залишки мильного розчину усуваємо тампоном зволоженим теплою дистильованою водою, та сухим забираємо залишкову вологу з очищених ділянок. Повністю просушене малярство покриваємо захисним шаром лаку. Одну сторону ми підготували до завершального процесу - реставраційних тонувань.

Далі розпочинаємо реставрацію іншої сторони, де проводимо ідентичні процеси, за винятком повного укріплення живопису. Провівши укріплення першої сторони, ми частково вже відновили адгезію грунту 3 фарбовим шаром i основою і на протилежній стороні. Тому тепер використовуємо відкритий, локальний спосіб укріплення на окремих ділянках. Разом з тим проклеюємо місця втрат авторського грунту, для кращого зчеплення реставраційного грунту з авторською основою. Усі подальші реставраційні процеси ідентичні проведеним на попередній стороні малярства (рис. 5).

Після завершення усіх процесів приступаємо до процесу тонувань та реконструкції втрат авторського малярства. Тонування проводимо олійними фарбами методом «пуантель». Даємо тонуванням повністю 
висохнути та покриваємо обидві сторони малярства захисним шаром лаку. Виготовляємо та монтуємо дві горизонтальні планки 3 наконечниками для подальшого експонування пам'ятки. (рис. 7, рис. 8).
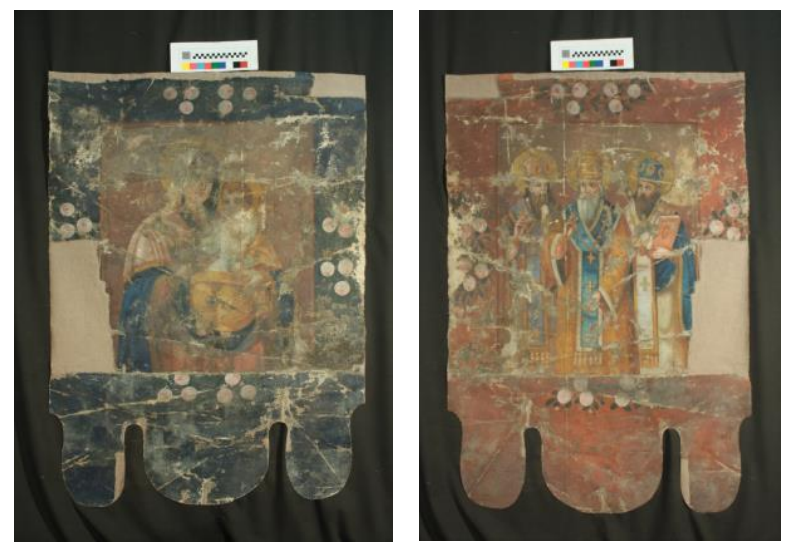

Рис. 5., Рис. 6. Загальний вигляд твору в процесі реставрації. (укріплення, склеювання частин, доповнення втрат основи) Сторона А, Сторона Б
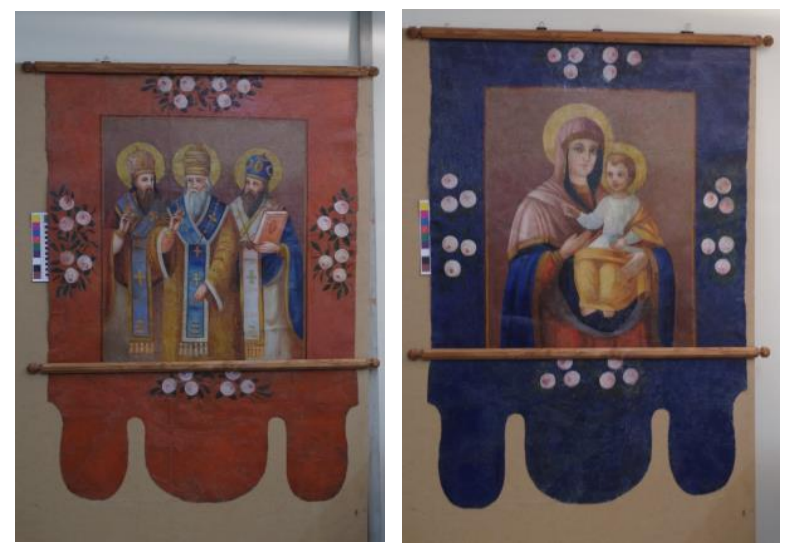

Рис. 7., Рис. 8. Загальний вигляд твору після проведення реставраційних заходів. Сторона А, Сторона Б 
Реставрація таких складних творів потребує великого досвіду і відповідального ставлення до роботи реставратора 3 високою кваліфікаційною категорією. Реставратор без категорії повинен обов'язково працювати під керівництвом більш кваліфікованого працівника.

\title{
Література:
}

1. https://nml.com.ua/pro-muzey/korotko-pro-muzey/

2. Косів Роксолана Романівна. Українські хоругви XVII-XVIII ст.

DOI https://doi.org/10.30525/978-9934-26-004-9-68

\section{ВІЗАНТІЙСЬКО-КИЇВСЬКІ ДЖЕРЕЛА УКРАЇНСЬКОГО ІКОНОСТАСА}

\author{
Шевлюга О. А. \\ кандидат мистецтвознавства, \\ старший викладач кафедри історії і теорії мистецтва \\ Національної академії образотворчого мистецтвва і архітектури \\ м. Київ, Украӥна
}

Вівтарні перегорожі в Київській Русі були успадковані з Візантії, 3 прийняттям християнства при Київському князі Володимирі наприкінці $\mathrm{X}$ ст. 3 часом вівтарні перегорожі українських храмів трансформуються в низький іконостас під впливом відповідних змін у церквах країн візантійського ареалу. Одна із суттєвих рис у генезі українського іконостаса - тяглість іконографічних взірців, відомих у візантійськокиївському мистецтві. Серед них намісний образ Христа Пантократора на повний зріст, знаного в українському мистецтвознавстві як Христос Учитель або Милостивий: с. Вільче XV ст., с. Милик XV ст., c. Старичі XV ст., інші [5, с. 119]. В українських іконостасах такі ікони розміщувались у намісному ряді, наслідуючи візантийські приклади. Певний час побутувала думка про пізню появу в українському мистецтві цього іконографічного типу, але нам вдалось віднайти ряд пам'яток часів Київської Русі з подібною іконографією: київський хрест-енколпіон XIIXIII ст., 3 Державного історичного музею в Москві, енколпіон близько 1200 р. із Музею історії міста Києва, два срібних кратера першої чверті XII ст. із Новгородської Софії, інші [8, с. 280; 7, с. 88-89; 9, с. 64]. 